\title{
ACUTE MYELOID LEUKAEMIA WITH LEUKAEMIC DEPOSIT IN THE ORBIT*
}

BY

\author{
B. M. CHATTERJEE AND N. N. SEN
}

From the Department of Ophthalmology and the Division of Haematology, Department of Pathology and Bacteriology, Institute of Postgraduate Medical Education and Research, S.S.K.M. Hospital, Calcutta

ORBITAL infiltration is fairly common in association with acute or chronic lymphatic leukaemia. A bilateral proptosis was observed to occur in 2 per cent. of cases of lymphatic leukaemia by Reese and Guy (1933). Myelogenous leukaemia only very rarely gives rise to a similar orbital infiltration (Duc, 1937; Wright, 1938; Duke-Elder, 1952). Wright's case showed a hard mass in each orbit projecting beneath the supra-orbital margin in a 4-year-old Indian child, with fever and a blood picture of acute myeloid leukaemia. The following is the report of a case of acute myeloid leukaemia with leukaemic deposit in the right orbit only.

\section{Case Report}

A Hindu male child aged 5 years attended the Ophthalmic Department of the S.S.K.M. Hospital, on April 27, 1959, with a history of the right eye being pushed forwards for the

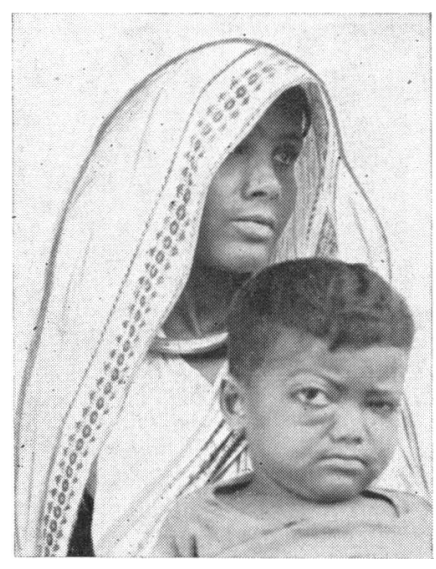

Fig. 1.-Right eye pushed forward with moderate fullness of lower eyelid. last 2 months. There was no other associated symptom either local or general (Fig. 1).

Ophthalmological Examination.-The right eyeball was pushed forwards and slightly sideways and upwards with restricted movement in all directions. There was neither congestion nor chemosis of the conjunctiva. A moderate fullness occupied the entire extent of the lower lid. Corresponding to the fullness of the lid, a hard crescentic mass could be felt just above the inferior orbital margin, extending from the inner to the outer canthus parallel to the orbital margin. The mass was immobile, slightly irregular, but not tender to the touch, and spread inside the orbit underneath the eyeball, so that the posterior limit could not be ascertained. The skin of the lower lid was tense but not adherent to the underlying mass. Regional lymph nodes were not enlarged. The fundus was normal and the vision was not impaired.

The left eye and orbit were normal in all respects.

General Examination.-There was no enlargement of liver, spleen, or lymph nodes. The air sinuses were normal. There was no fever and the child appeared healthy.

* Received for publication August 8, 1959. 
Peripheral Blood

$\begin{array}{lllllllll}\text { Red blood cells } \ldots & \ldots & \ldots & \ldots & \ldots & \ldots & \ldots & 3 \cdot 2 \text { million } / \text { c.mm. }\end{array}$

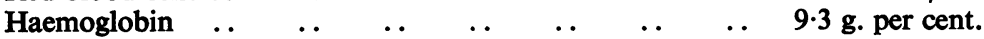

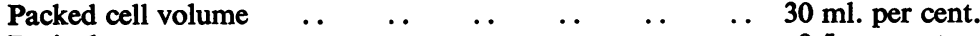

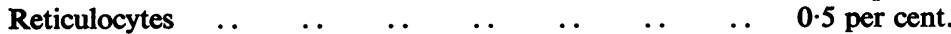

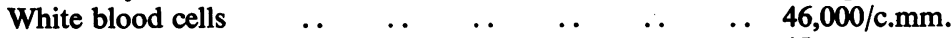

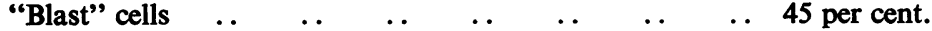

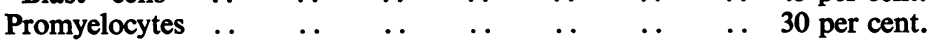

$\begin{array}{lllllllll}\text { Myelocytes } & \ldots & \ldots & \ldots & \ldots & \ldots & \ldots & \ldots & 5 \text { per cent. }\end{array}$

$\begin{array}{llllllll}\text { Metamyelocytes } & \ldots & \ldots & \ldots & \ldots & \ldots & \ldots & 5 \text { per cent. }\end{array}$

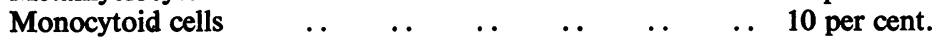

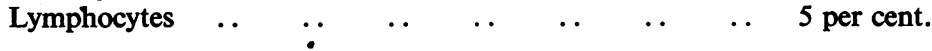

\section{Sternal Marrow}

Bone marrow hypercellular

Differential marrow cell count (per cent.)

$$
\begin{array}{lllllllll}
\text { "Blast" cells } & . . & . . & . . & . . & . . & . . & . . & 80 \\
\text { Promyelocytes } & . & . . & . . & . . & . . & . . & . . & 10 \\
\text { Myelocytes .. } & . . & . . & . . & . . & . & . . & . . & 3 \\
\text { Metamyelocytes } & . . & . & . . & . . & . & . & . . & 2 \\
\text { Proerythroblasts } & . . & . & . . & . . & . & . & . & 1 \cdot 5 \\
\text { Normoblasts } & . . & . & . . & . . & . & . & . . & 3.5
\end{array}
$$

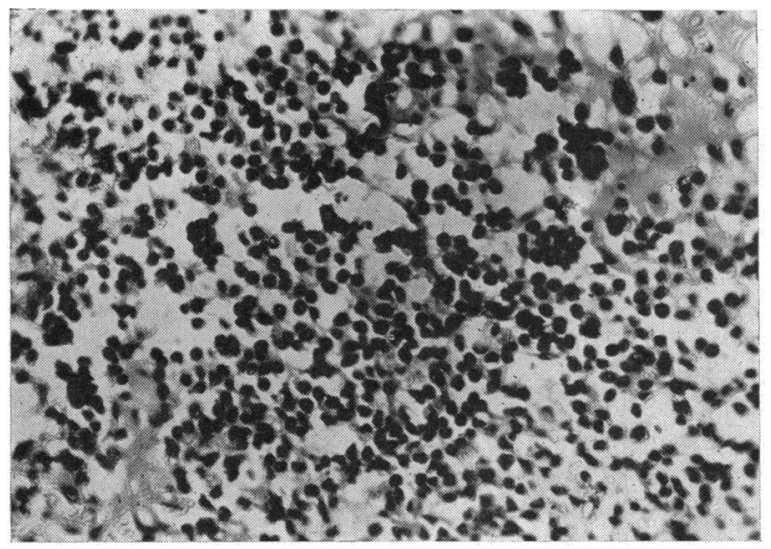

Discussion

Biopsy from Orbital Mass.The conjunctiva was incised through the inferior fornix and a pale white mass was exposed. It was cartilaginous in consistency and did not bleed on section. Histologically, the tissue showed a focal collection of leukaemic cells in a fairly dense fibrous matrix (Fig. 2).

Skiagram.-The right orbit showed no bony involvement.

FIG. 2.-Histological section of biopsy from orbital mass, showing focal collection of leukaemic cells in a fairly fibrous matrix.

Acute myeloid leukaemia may manifest itself with diffuse infiltration in various organs or very rarely in localized deposits of leukaemic cells. The peripheral blood, the sternal marrow, and the new-formed tissue in the orbit proved that the present case was a rare instance of acute myeloid leukaemia with orbital deposit.

A rare pathological condition, chloroma, is also known to exist as a variant of myeloid leukaemia in which a prominent feature is the deposition of greenish-yellow tumour-like masses in the skeleton, especially the skull (and orbital regions), the lymph nodes, and the viscera (Sturgis, 1955). Orbital involvement by tumour masses giving rise to exophthalmos occurs in approximately 50 per cent. of all instances of chloroma (Sorsby, 1951). Though some of the patients reported as cases of chloroma had white 
tumours (Hirschfeld, 1917; Rowe and Hirschboeck, 1922; Pagniez, Coste, and Ravina, 1924; Kemp and Williams, 1941), Frost (1937) is cited by Tassman (1950) as supposing that the tumour must be green in colour in order to be designated a chloroma. Humble (1946) considered that the essential feature of chloroma is the green pigment, and Ross (1955) suggested that the term chloroma should be reserved for cases showing green pigment.

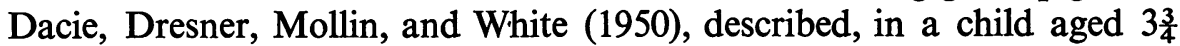
years, massive peri-orbital infiltration of both eyelids, leading to intense swelling in association with acute myeloid leukaemia. Autopsy showed enlargement of the kidneys with white infiltrating nodules and infiltrations in the pancreas and the gastric mucosa. The case was not classed as one of chloroma, obviously because the green colour was absent. Mathur (1959) reported four cases of chloroma of the orbit; the tumours in his first two cases were green, but the colour of the tumours in the other two cases was not mentioned. Hameed, Das, and Agarwal (1959) described two cases of acute leukaemia with orbital deposits. Their diagnosis was chloroma although the colour of the neoplasm was not mentioned.

It is apparent, therefore, that, with the same underlying pathological condition of the haemopoietic tissue, in certain cases only, the white cell deposits and tumour masses are pigmented. It is not clearly understood whether a leukaemic deposit in the tissues represents a different phase of the same disease as that causing a chloroma, or whether the tumours are qualitative variants of acute leukaemia.

\section{Summary}

A case of acute myeloid leukaemia in a child with leukaemic deposit in the right orbit is reported. The differentiation from chloroma of the orbit is discussed.

Our thanks are due to Prof. B. K. Aikat, Director of the Department of Pathology and Bacteriology, for the histological report, and to Maj.-Gen. A. K. Gupta, Surgeon Superintendent, S.S.K.M. Hospital, for permission to publish this case.

\section{REFERENCES}

Dacie, J. V., Dresner, E., Mollin, D. L., and White, J. C. (1950). Brit. med. J., 1, 1447.

Duc, C. (1937). Rass. ital. Ottal., 6, 719. (Quoted by Duke-Elder, 1952).

DUKE-ELDER, S. (1952). "Text-book of Ophthalmology", vol. 5, p. 5552 . Kimpton, London.

FROST, A. D. (1937). Trans. Amer. Acad. Ophthal. Otolaryng., 42, 123. (Quoted by Tassman, 1951).

HAMEED, S., DAS, T., and AgARWAL, K. C. (1959). Brit. J. Ophthal., 43, 107.

HIRSCHFELD, H. (1917). Z. Krebsforsch., 16, 86. (Quoted by Ross, 1955).

Humble, J. G. (1946). Quart.J. Med., 15, 299.

KeMP, T. A., and Williams, E. R. (1941). Brit. J. Radiol., 14, 157.

Mathur, S. P. (1959). Amer. J. Ophthal., 47, 91.

Pagneiz, P., Coste, F., and Ravina, A. (1924). Ann. méd. Paris, 16, 416. (Quoted by Ross, 1955).

REESE, A, B., and GUY, L. (1933). Amer J. Ophthal., 16, 718.

Ross, R. R. (1955). Amer. J. Med., 18, 671.

ROWE, O. W., and HIRSCHBOECK, F. J. (1922). Amer. J. Dis. Child., 24, 239.

SorsBY, A. (1951). "'Systemic Ophthalmology", p. 574 . Butterworth, London.

STURGIS, C. C. (1955). "Hematology", 2nd. ed., p. 862. Thomas, Springfield, Ill.

TASSMAN, i. S. (1950). "The Eye Manifestations of Internal Diseases", 3rd. ed., p. 512. Kimpton, London.

Wright (1938). "Extra-ocular Affections". Madras. (Quoted by Duke-Elder, 1952). 